\title{
Palpable Masses Original Result
}

National Cancer Institute

\section{Source}

National Cancer Institute. Palpable Masses Original Result. NCI Thesaurus. Code

C119911.

The outcome of the palpable masses assessment as originally received or collected. 